\title{
Analysis of Tourism Promotion Strategies Through Twitter Social Media: A Case Study in Yogyakarta
}

\author{
Danang Kurniawan ${ }^{1}{ }^{*}$, Herpita Wahyuni ${ }^{2}$, Arissy Jorgi Sutan ${ }^{3}$ \\ 1,2,3 Master of Government Studies, Universitas Muhammadiyah Yogyakarta \\ Jl.Brawijaya, Kasihan, Bantul, Yogyakarta, Indonesia, 55183 \\ *Corresponding Author: danangumy@gmail.com
}

\begin{abstract}
Social media helps deliver information efficiently, Yogyakarta Government used social media to provide information on Yogyakarta's tourism to society, mainly the local or foreign tourists. This research aims to see the strategy of delivering news of the City of Yogyakarta government to promote the tourism destination during the covid-19 pandemic transition period, using social media account @Jogja/Yogyakarta of City of Yogyakarta government in Twitter. This research used the qualitative approach with application-based used, or (Qualitative Data Analysis Software) the software used in this research is NVivo 12 plus. In the part of the analysis used NVivo 12 Plus, begin with: (1) capture the data, (2) Import the information, (3) Coding the data, (4) Classification the data, and (5) Display the data. This research shows that to promote tourism in Yogyakarta City applied with the integrated and consistent, after the Phenomena of Ciovid-19. Strategy to deliver the information focused on attracting the tourist to visit with applied the health protocol strictly, so that cerate the new culture that aims to reduce the spread of Covid-19, by limiting capacity, using Jogja Smart Service in monitoring the number of visitors.
\end{abstract}

Article Info :

Article history :

Received: December 5, 2020 Revised: February 28, 2021 Accepted: March 31, 2021

Keywords: social media; tourism; yogyakarta

\section{INTRODUCTION}

In this era, governance becomes transform in the duties and functions because of the Pandemic Covid-19. These situations become new problems for the government to respond to and adjust efforts in public service. The first case of Covid-19 happens in Wuhan City, Hubei Province, People's Republic of China; this virus-infected in many regions and countries and the impacts on the governance sector like Public service, International economy, and tourism. The impact also in the tourism aspect with trouble on development of tourism. in this case like the country which have strong tourism 
industry like Portugal get more negative impact from the pandemic (ALMEIDA \& SILVA, 2020). The tourism sector was hit hardest because of the social distancing policy and its relevance with the decreased number of visitors to the tourism destination, so the local government income (PAD) declined in the district with the tourism industry (Soehardi, Permatasari, \& Sihite, 2020). Covid-19 become the new challenge in the tourism industry, especially to the management of tourist destination to keep promoting the "save tourism destination" and implemented the health protocol of Covid-19. To hold the tourism activity in the transition period, be aware of the health protocol Covid-19, like always used health mask, hand sanitizer, and Physical distancing protocol should be narration that socializes on tourism destinations in the new normal conditions (Soehardi et al., 2020).

Social media, in this case, can give more advantages like to promotion of tourism. On the other side, using social media can give a new type of marketing tourism. We use social media to promote the tourism destination more efficiently, cheaper, and get more large range. Integrated Marketing Communication (IMC) is a strategy to communicate all the same messages or values in all marketing channels. IMC aims to disturb society using the element of promoting down to the level of cognition, affection, and conation (Belch \& Belch, 2004). Social media will be the rights platform to promote tourism and another product because social media has the massive user and situation of pandemic Covid-19 and impacts advertised development and tourism using social media (Surijah, Kirana, Wahyuni, Yudi, \& Astini, 2017; Herdiana, 2020; Khasanah, 2020; Mistriani, Maria, \& Damayanti, 2020; Gössling, Scott, \& Hall, 2020).

According to The Jakarta Post, Yogyakarta reportedly welcomed 1,7 million tourism during July until November 2020; the data from two applications there are Visiting Jogja and Jogja Pass (Post, 2020). The cities with a strong tourism sector like Bandung, Yogyakarta, and Bali are now using social media to promote tourist destinations in their respective areas. Yogyakarta's city used social media Twitter to promote the tourism sector. There is also a Jogja Smart service to guide the tourism destination to obey the health protocol in every single tourism destination in Yogyakarta. the City of Yogyakarta governance have done an innovation in the tourism service in this practice using Jogja smart service and give the tourism, and the promotor fell save to do the tourism activities during the pandemic Covid-19 (Bakti, 2018; Lestari \& Saifuddin, 2020; Trihayuningtyas, Wulandari, Adriani, \& Sarasvati, 2018; Umami, 2015).

There has been previous research explaining the impact of Covid 19 on the tourism industry. The study results show that the Taiwanese government proposes various relief and revitalization measures to the hotel industry in response to the COVID-19 epidemic (Fu, 2020). Then, research related to tourism development strategies in the Covid 19 pandemic era previously focused on the region's tourism pandemic, which predicts tourism behavior tends to be planned and will initiate travel preferences (Wachyuni \& Kusumaningrum, 2020). Alternative tourism policies are considered capable of overcoming the problem of local revenue in Palembang City, including increased guidance and government attention to aspects of tourism, increasing professional human resources in the field of tourism, the intensity of tourism promotion, and alternative policies to improve support facilities and ensure the safety

78| Journal of Local Government Issues (LOGOS), 4 (1), March 2021, pp 77- 89 ISSN : 2620-8091 print | 2620-3812 online 
of tourists in the face of a pandemic. Covid-19 is currently in a new era (Lionardo, Kurniawan, \& Nasirin, 2020).

The same research looks at the relationship of sustainable tourism customers in implementing customer strategies to contact tourism service customers with nonintrusive techniques at the beginning of the buying process and accompanying them to the final transaction (Sánchez-Teba, García-Mestanza, \& Rodríguez-Fernández, 2020). As for the difference from previous studies, this study looks at the social media function of the Yogyakarta Government in the communication process in the tourism sector. This research has two big questions, Q1 How can social media be used in the communication process of tourism promotion, including planning, making, integrating, and marketing strategies in the Yogyakarta Region during the Covid-19 Pandemic? Q2 What content is the Special Region of Yogyakarta (DIY) government's strategy in increasing tourists visited Yogyakarta. This research also has a novelty value that is still lacking in social media research as a tourism strategy promotion in the Covid 19 Pandemic era. This study's limitations are only looking at social media managed by the government, which does not see social media as a whole related to the perpetrators tours in DIY Yogyakarta.

\section{METHOD}

This research focused on the efforts in utilizing social media in conveying the communication process, which consists of planning, creating, integrating, and tourism promotion strategies for the Yogyakarta City Government using social media account Twitter @Jogja/Yogyakarta to get the attention and bring more tourist in the pandemic Covid-19 and new normal situation. This research used the qualitative approach used to analyze software NVivo 12 plus (see Figure 1). It explored the data using four analyze; there is a Timeline by Month Analyze from July 2020 (The beginning of New Normal) until November 2020.

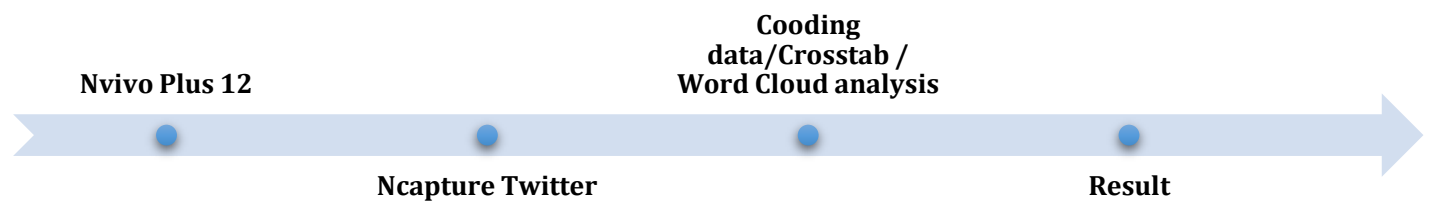

Figure 1. Research Framework

The second analysis is Crosstab Query with the code's entry (manual, automatically), the text data, numerical to identify variables, and data pattern. The third analysis is Word Cloud to found the dominant word on the topics. The fourth analysis is Word Tree to see the connectivity and pattern in this research. This research found the communication strategy that includes planning, creation, integration, and marketing strategy (Iswandi, 2010).

\section{RESULTS AND DISCUSSION}

City of Yogyakarta governance tried to develop the tourism sector optimally; this sector became the region's primary income. The tourism sector will rise and become the country's primary income, and the tourism sector will be equal to another industry, the

79| Journal of Local Government Issues (LOGOS), 4 (1), March 2021, pp 77- 89 ISSN : 2620-8091 print | 2620-3812 online 
tourism sector can call the tourism industry . Communication strategy to promote the tourism sector in the City of Yogyakarta during the social distancing policies will be a strategical step to increase visitors' number. Used Integrated marketing communication by the governance city of Yogyakarta has been implemented step by step from Planning, Creation, Integration, and Marketing Strategy (Iswandi, 2010). The governance City of Yogyakarta to delivered information to promoted tourism sector moved with dynamic, we can see from January until October 2020.

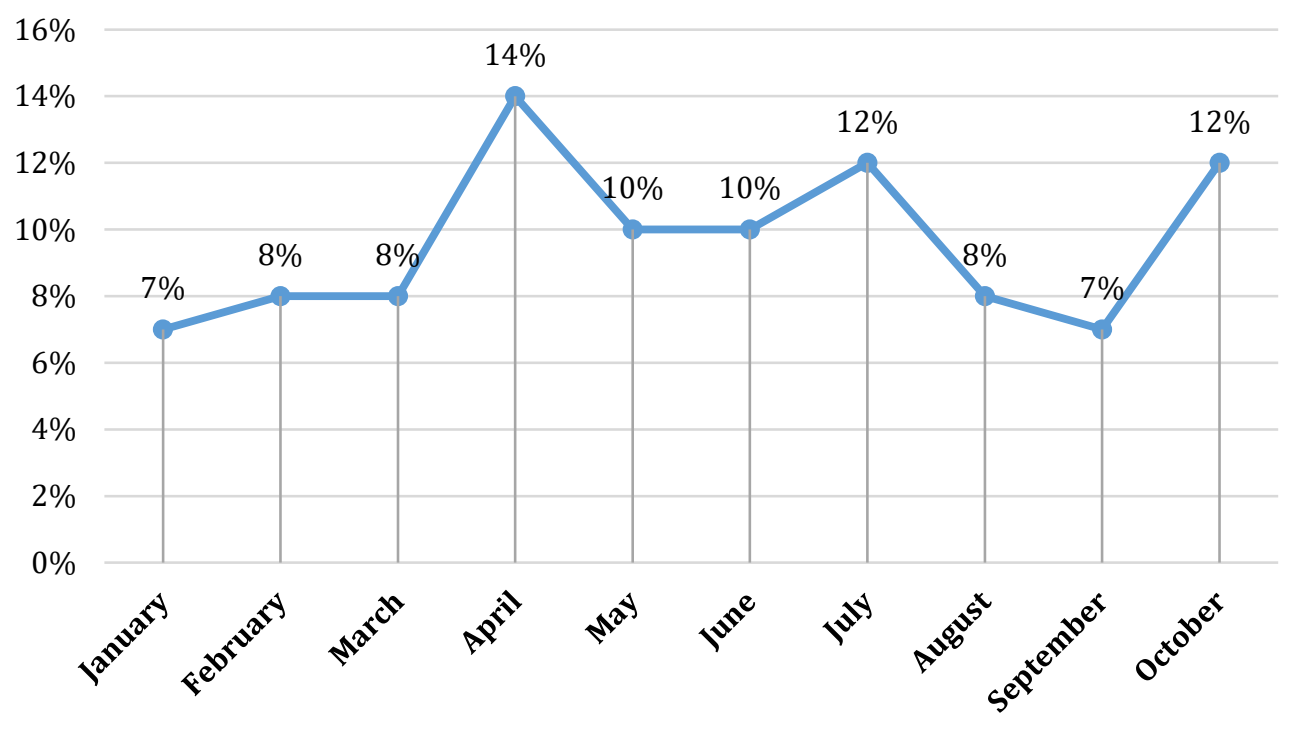

Figure 2. Yogyakarta City Government social media account activities in 2020

The governance City of Yogyakarta delivered the information move with fluctuating in every month in 2020 from January until October (see Figure 2). In April it reaches the highest activities percentage with 14\%. The second happened in July, and October, with a $12 \%$ percentage. If we see universally, delivering information by the city of Yogyakarta governance increased in April and then dropped in May and June with the same score of $10 \%$. In July Increased by $2 \%$ better than June, the score drops again until September with the value is $5 \%$ and then increased in October with the presentation of $12 \%$. Yogyakarta's governance city's social media account activity is part of promoting the new normal era's tourism destination. Conversation, mainly not a conversational function, suggests Twitter is used as a broadcasting tool in the context of providing insight into anything related (Jacobson, Degener, \& Purcell-Gates, 2003). The strategy of delivering information through social media accounts posting activities @ Jogja / Yogyakarta is carried out consistently and regularly (see Figure 3). 


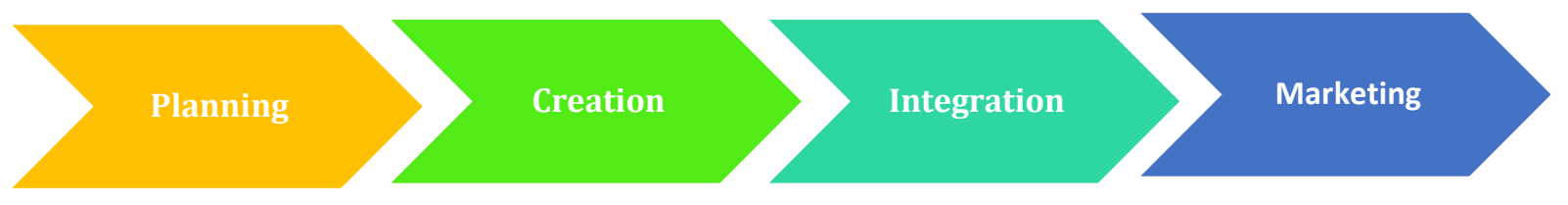

Figure 3. Information communication delivery strategy stages

The strategy is part of the successful delivery of promotional information. If we look at the whole step government city of Yogyakarta like planning, Creation, Integration, and Marketing (see Figure 3), we have a content percentage that is not much different. The process of delivering information is integrated to give the consumer some knowledge and respond to accommodate what they need and develop progressive information (Shimp, 2003).

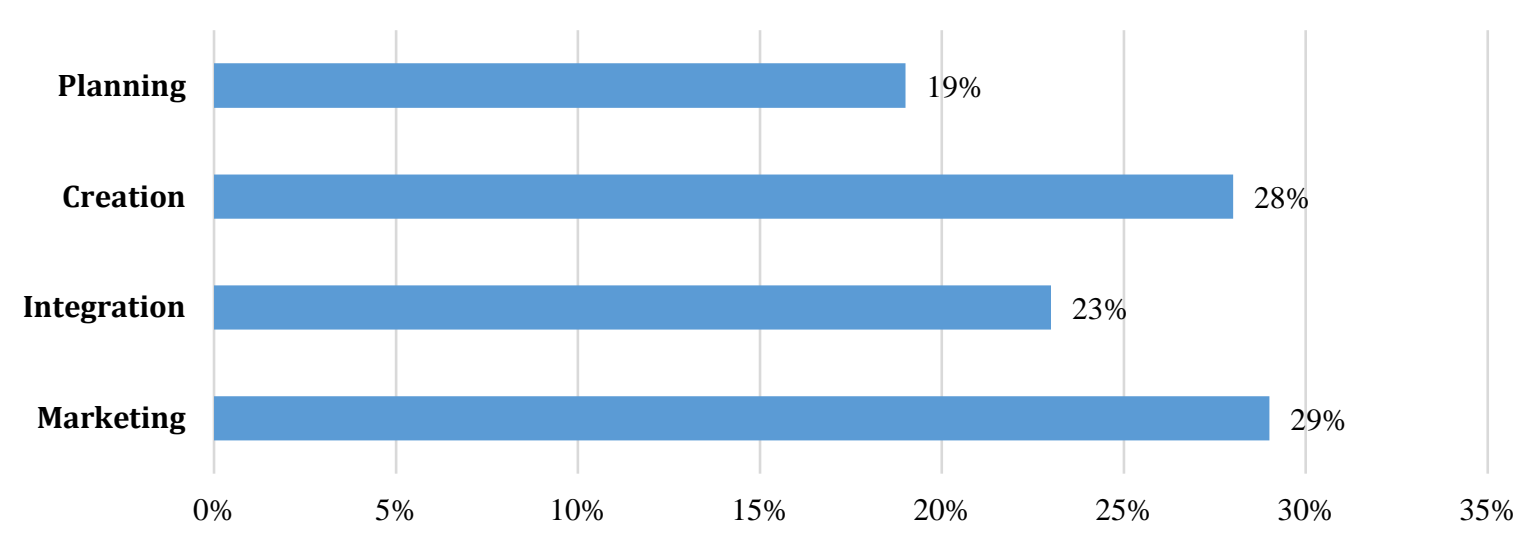

Figure 4. Crosstab Query

Using social media to deliver information (see Figure 4), in this case, the social media account of @Jogja/Yogyakarta shows that there found some connection between creation and marketing has the same proportion. The creation and marketing aspects become critical to increasing promoted tourism after the pandemic Covid-19 in Yogyakarta. That tow aspect has the highest percentage with a score of $29 \%$, then the integration aspect of delivering information has a score of $23 \%$, higher if compared with planning with a score of $19 \%$. Aspect creation has a score of $28 \%$. All aspects of the strategy for delivering information integrated marketing communication (IMC) in Yogyakarta are related to one another; it can be seen from the insignificant number of percentages.

Integrated Marketing Communications (IMC) uses different communication mix elements to create mutually supportive coherence (Susilana, 2007). The researcher presents an analysis of every aspect of the stages of information delivery carried out by the Yogyakarta City Government as part of a sustainability strategy through social media Twitter. Delivering information from the Yogyakarta City Government, analyzed 
using three analysis methods. The first is the crosstab query, the second is the Word tree, and the third is the Word cloud used to present the strategic process.

\section{Planning}

Analyzing data from Twitter account @Jogja/Yogyakarta From July until November 2020 shows a percentage of 19\% from all delivered. Urban planning builds differentiation and strengthens city identity to attract tourists, investors, reliable human resources, industry and improve relations between citizens and cities (Yananda \& Salamah, 2014). Haryadi Suyuti, as Mayor of Yogyakarta City, has been asking for the need for rigorous preparation in monitoring health protocols in the main tourist area of Malioboro street. Tweet activity can be seen in the excerpt below. Tweet activity can be seen in the section below.

"Siap-siap \#Jogja ! Tidak Memakai Masker di Tempat Umum, Bakal kena Sanksi Denda Rp 100 ribu https://t.co/tmgSeCPEpEvia @yogyakartacity"

Strategy planning is a concept talks about steps to create some strategy (Griffin, 2004). Planning focused on strengthening normatively in reducing the spread of Covid 19 in the City of Yogyakarta. Supervision in offices and non-governmental offices in carrying out offenders' health protocols can be subject to sanctions accordingly; Governor Election of Yogyakarta Number 77/2020 talks about health protocol discipline. Regarding Health Protocol Disciplinary Enforcement. The Yogyakarta City Government prepared a plan by focusing on creating order in the Yogyakarta City environment and distributing 130,000 cloth masks carried out until November 2020, which was part of a disciplinary campaign to use shows. Tweet activity can be seen in the excerpt below.

“Pemkot Jogja akan Bagikan 130.000 Masker Kain. https://t.co/RCAAhuZaXL via @yogyakartacity'

Planning is an integral part of every job (Morrisan, 2015). Distribute vaccine Covid-19 from the capital will be distributed step by step. Distribute vaccine used priority list from vulnerable groups and those engaged in the health sector. The first phase will be distributed at the age of 18-56 years. The vaccine is planned to be distributed to as many as 100 million throughout the province. Besides, vaccine distribution in Yogyakarta focused on delivering information related to handling Covid19 in the City of Yogyakarta so that this condition will be a significant asset in creating a safe zone in the City of Yogyakarta.

\section{Creation}

Public service in the tourism sector in the city of Yogyakarta reopened by applying the health protocol straightly. It used punishment, such as pay the penalty of 100.000 Indonesian Rupiahs if people do not wear a mask. Many tourism destinations used to trial to limited visitors. Creating a sense of security and creating a sense of trust in the government is essential in a region's progress, including during a pandemic.

82| Journal of Local Government Issues (LOGOS), 4 (1), March 2021, pp 77- 89 ISSN : 2620-8091 print | 2620-3812 online 
Creation is a stage that focuses on the Yogyakarta City Government's communication strategy, evidenced by the percentage $(28 \%)$. Based on information from the Head of management of Malioboro Area (UPT), Ekwanto stated a capacity zone in Malioboro. The capacity of each in the area is 500 people at a time. Tweet activity can be seen in the excerpt below.

"Pengunjung Malioboro Melebihi Kapasitas, maka Alarm akan Berbunyi https://t.co/Fv3XBF8NPkvia @yogyakartacity".

The facility's tourism sector element is public space, information, worship room, security (Gunn \& Var, 2002). Creating a sense of security for each visitor can be monitored through the Jogja Smart Service application. The capacity that exceeds the limit will be detected and will cause an alarm sound, which indicates that it is not allowed to enter the zone. The strategy carried out by the government (DIY) will undoubtedly reduce the fear of visitors because of the control of capacity in each area, and these activities make visitors feel courageous and, of course, comply with the prescribed health protocols. The creation and use of the Jogja Smart Service application are undoubtedly beneficial in a pandemic period to control the crowd so that visitors have space and a sense of security by following established procedures.

\section{Integration}

The implementation of cooperation between elements in reducing the transmission of Covid-19 and communication strategies in tourism in Yogyakarta City earned a score of $23.00 \%$. Yogyakarta is known as a city that is rich in tourism and distinctive culinary delights. To overcome the spread of Covid-19, the Yogyakarta city government continues to strive to improve and record health services. Information delivery (IMC) is a mere promotion mix and communication mix, but an integrated or integrated element becomes very important in supporting its implementation (Estaswara, 2008).

Civil service police unit tried to supervise, regularly remind to maintain distance, and always wear a mask with the discipline health protocol implemented by the Bantul Regency Government to the villages. The Regional Secretary of Sleman Harda Kiswaya, on October 6, 2020, stated that there had been an operation to enforce the Health protocol together with the civil service police Unit, especially preventing wearing masks and providing guidance for offenders. The Jogja/Yogyakarta Twitter account in attracting travel enthusiasts by using protocol Health is considered adequate, which can be seen from the cohesiveness of various elements in realizing the importance of maintaining Health and firmness protocol sanctions for violators in public places such as in the monument, market, and monetary penalties in the form Malioboro 100 thousand. Mentions activities undertaken to support success in attracting tourists can be seen in the table below. The table below shows Mentions in an Integrated Context. 
Kurniawan

Table 1. Mentions in Tweet

\begin{tabular}{|c|c|c|}
\hline Tweet & Mentions & Amount \\
\hline $\begin{array}{l}\text { What kind the Government DIY do to eradicating } \\
\text { covid-19, and make the policy can implemented } \\
\text { with optimum. } \quad \text { https://t.co/rofKnVEqzPvia } \\
\text { @yogyakartacity }\end{array}$ & @yogyakartacity & 1 \\
\hline $\begin{array}{l}\text { The penalty about Health Protocol in city of } \\
\text { Yogyakarta will be implemented in this night. } \\
\text { https://t.co/xrD1SVVDILvia @yogyakartacity }\end{array}$ & @yogyakartacity & 1 \\
\hline $\begin{array}{l}\text { Noted, this is the message from the security } \\
\text { bodyguard city of Jogja, to everyone who wants to } \\
\text { eat at the restauranthttps://t.co/rY4Mhy09VPvia } \\
\text { @yogyakartacity }\end{array}$ & @yogyakartacity & 1 \\
\hline $\begin{array}{l}\text { The enforcement of health protocols in Sleman, } \\
\text { has been implemented in villagers also. } \\
\text { https://t.co/G0G7vSbsarvia @yogyakartacity }\end{array}$ & @yogyakartacity & 1 \\
\hline $\begin{array}{l}\text { Some people breaking the health protocol to } \\
\text { wear masker, and should take responsibility, } \\
\text { when the raid of health protocol near the } \\
\text { TuguJogja. } \\
\text { https://t.co/mJvywtehvg }\end{array}$ & @yogyakartacity & 1 \\
\hline $\begin{array}{l}\text { Although the emergency response period was } \\
\text { extended, the Governor of Yogyakarta Special } \\
\text { Region, Sri Sultan HB X, has invited economic } \\
\text { activities, especially the tourism sector, to resume } \\
\text { operations. Health protocols must be } \\
\text { implemented, the data of each visitor must also be } \\
\text { recorded.https://t.co/qbKONlnXLy } \\
\text { @yogyakartacity }\end{array}$ & @yogyakartacity & 1 \\
\hline $\begin{array}{l}\text { This is the Sultan's hope for tourists visiting } \\
\text { Malioborohttps://t.co/UjnrVcOTZLvia } \\
\text { @yogyakartacity }\end{array}$ & @yogyakartacity & 1 \\
\hline
\end{tabular}

Source: Data processed by researchers (2020) with NVivo 12 Plus (2020

That data shows the activities mentions on the Twitter account Jogja/Yogyakarta and gives information that the Governor of the Special Region of Yogyakarta has been told to allow the economic activities and tourism industries but must apply health protocol tracking the number of visitors. Integration in DIY has been giving president Jokowi to prevent and fast reaction to break the chain of Covid-19 on 15 July 2020. The governance of DIY tried in many actions preventing in this case that is waves of travelers, conducting intensive case tracking, holding regular appeals from the government, and producing innovations during the pandemic. The findings show that cooperation is created well so that activities in improving the economy through the tourism sector in DIY can continue to be controlled and generate trust between the government and the community so that tourism in DIY can continue running. 


\section{Marketing}

The application of DIY tourism marketing during the New Normal era is now based on the findings and data processing obtained a score (29\%). The strategy that emerged from the result that tourism in (DIY) has been opened by implementing health protocols and capacity restrictions. The Jogja/Yogyakarta Twitter account is an account that has a good marketing strategy, as seen from various Tweets such as the Tweet on October 30, 2020, which features a beautiful view of Malioboro and is decorated with lighting that resembles regular times but with the condition of visitors by following the Health protocol and close supervision of officers. Economic marketing has also emerged, namely the opening of a cinema with stringent Health protocols, namely using a mask, keeping the distance, checking body temperature, and always using a hand sanitizer for every cinema visitor. On July 1, 2020, a Tweet that reminds the citizen of the comfort and understanding of Jogja appeared; namely, a Tweet that reads "Stay friendly even though smiles are covered with masks and face shield" and various Tweets that tell you about the beauty of the city of Yogyakarta from sharing aspects, especially aspects of tourism. The marketing strategy offered opens up opportunities to increase tourism with specified conditions. The tourism and culinary marketing strategies carried out can increase tourism without neglecting the Health protocol. The implementation of growing tourism in DIY's new normal conditions can be seen in Figure 4 below.

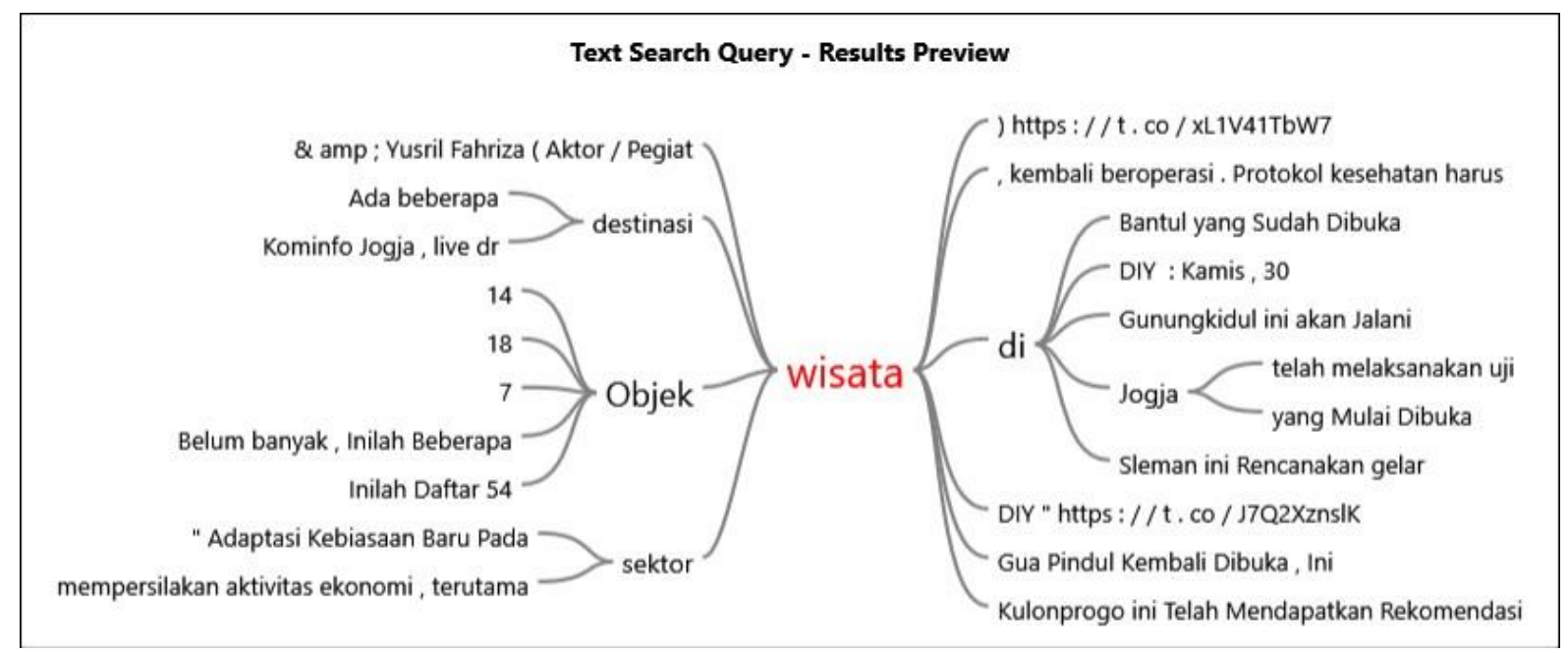

Figure 4. Word Query Tourism New Normal DIY with NVivo 12 Plus (2020)

The strategy in increasing new normal tourism with the Health protocol from the account data witter @ Jogja / Yogyakarta can be seen that there is a pattern of relationship between related elements, among others, that tourism in (DIY) is reopened by applying the provisions of the excellent health protocol and the existence of strict supervision in activities tourism in Malioboro, monuments and all aspects of tourism that will provide mutual comfort and high alertness. Data analysis results found that there were ten most famous words in the discussion, namely: via, Jogja, 
@yogyakartacity, DIY, covid, travel, health, protocols, masks, and 2020 which can be seen in Table 2 below.

Table 2. Most famous words

\begin{tabular}{ccc}
\hline Content & Amount & Presentase \\
\hline via & 41 & $25 \%$ \\
jogja & 29 & $18 \%$ \\
@yogyakartacity & 25 & $16 \%$ \\
\hline diy & 15 & $9 \%$ \\
\hline covid & 11 & $7 \%$ \\
\hline wisata & 10 & $6 \%$ \\
kesehatan & 9 & $6 \%$ \\
\hline protokol & 8 & $5 \%$ \\
masker & 7 & $4 \%$ \\
\hline 2020 & 6 & $4 \%$ \\
\hline
\end{tabular}

Source: Data obtained by researchers with NVivo 12 Plus (2020)

The data above raises a picture of the words that often appear in discussions of strategies to attract tourism in a new normal situation and apply health protocols. The results of data analysis found that there were ten most famous words in the discussion, namely: via, Jogja, @yogyakartacity, DIY, covid, travel, health, protocols, masks, and 2020 with the highest and lowest percentages of words via and 2020 , namely $25 \%$ and $4 \%$ which can be seen in Figure 5 below.

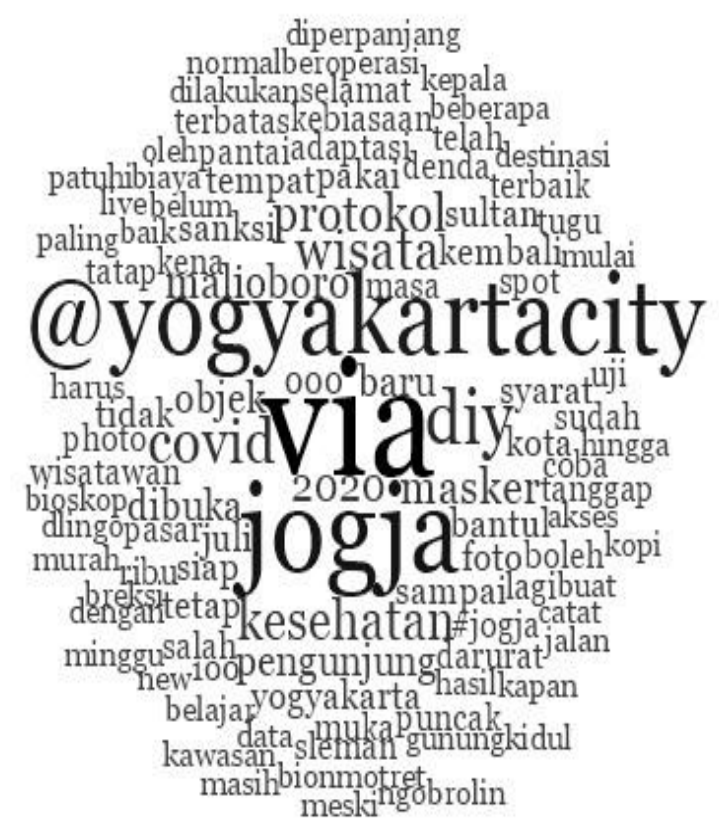

Figure 5. World Cloud 
The most dominant word that emerged from the Twiter Jogja / Yogyakarta account from data analysis with the NVivo 12 Plus world Cloud feature to increase tourism interest in the Special Region of Yogyakarta (DIY) in the era of the Covid-19 pandemic is the word via which means social media Twitter as a tool in conveying a variety of information which includes efforts and strategies to attract visitors to be able to do a destination by following the specified protocol. Other words that appear are Jogja, @yogyakarta, DIY. The name emerged from the implementation of marketing that focused on the scope of tourism in the Special Region of Yogyakarta (DIY). Then found the word "covid," which is a challenge faced in the present era. Special treatment is needed in tourism marketing strategies not to promote the importance of implementing health protocols. On this case we can see the tendency that the social media used to share the health protocol and to implemented them in the tourism sector. Beside that the word such @yogyakarta can give the attention and make the visitor fell save that Yogyakarta implemented the health protocol until the small sector of tourism.

\section{CONCLUSION}

The strategy in increasing tourism with social media Twitter through the Jogja / Yogyakarta account can be concluded that the strategy carried out through planning, creation, integration, and marketing has been implemented well . The activities carried out featured marketing strategies that could attract interest to visit with protocols that had to be followed correctly. The government made efforts to reduce the spread of Covid-19 by limiting capacity, using Jogja Smart Service in monitoring the number of visitors. There is firmness against violators of the inter-parliamentary Health and Cooperation protocol, namely the civil service police Unit in Raids activities and appeals with the Governor of Yogyakarta.

This research's limitation is the use of data in analyzing the topic using only social media data. Social media data is useful for seeing how the communication process and delivery occurs in the tourism sector in the Yogyakarta area. The recommendation for further research is to use data in highlighting the promotion of the tourism sector by looking at other media such as mass media and regional electronic media.

\section{REFERENCES}

Almeida, F., \& Silva, O. (2020). The Impact of COVID-19 on Tourism Sustainability: Evidence from Portugal. Advances in Hospitality and Tourism Research (AHTR), $8(2)$, 440-446. https://www.researchgate.net/deref/http\%3A\%2F\%2Fdx.doi.org\%2F10.30519 \%2Fahtr.775340.

Bakti, I. (2018). Pelatihan Komunikasi Pariwisata Berbasis Media Sosial (Instangram) di Kabupaten Pangandaran. Jurnal Pengabdian Kepada Masyarakat, 2(12), 10031006.

Belch, G. E., \& Belch, M. A. (2004). Advertising and Promotion: An integrated Marketing Communications Perspective 6th. New York: McGraw-Hill.

Estaswara, H. (2008). Think IMC: Efektivitas Komunikasi untuk Meningkatkan Loyalitas Merek dan Laba Perusahaan. Jakarta: Gramedia Putaka Utama.

87| Journal of Local Government Issues (LOGOS), 4 (1), March 2021, pp 77- 89 ISSN : 2620-8091 print | 2620-3812 online 
Fu, Y.-K. (2020). The Impact and Recovering Strategies of the Covid-19 Pandemic: Lessons from Taiwan's Hospitality Industry. Cogent Social Sciences, 6(1), 1829806. https://doi.org/10.1080/23311886.2020.1829806

Gössling, S., Scott, D., \& Hall, C. M. (2020). Pandemics, Tourism and Global Change: a rapid assessment of COVID-19. Journal of Sustainable Tourism, 29(1), 1-20. https://doi.org/10.1080/09669582.2020.1758708

Griffin, R. W. (2004). Manajemen. Jakarta: Erlangga.

Gunn, C. A., \& Var, T. (2002). Tourism Planning: Basics, Concepts, Cases. London: Routledge.

Herdiana, D. (2020). Rekomendasi Kebijakan Pemulihan Pariwisata Pasca Wabah Corona Virus Disease 2019 (Covid-19) di Kota Bandung. Jurnal Master Pariwisata (JUMPA), 7 (1) 1-30. https://doi.org/10.24843/JUMPA.2020.v07.i01.p01

Iswandi, A. M. (2010). Analisa Komunikasi Corporate Social Responsibility (CSR) Dalam Membangun Reputasi Perusahaan (Studi Kasus: Kampanye Lifebuoy Berbagi Sehat). Tesis: Universitas Indonesia.

Jacobson, E., Degener, S., \& Purcell-Gates, V. (2003). Creating Authentic Materials and Activities for the Adult Literacy Classroom: A Handbook for Practitioners. https://www.researchgate.net/publication/234717345_Creating_Authentic_Mat erials_and_Activities_for_the_Adult_Literacy_Classroom_A_Handbook_for_Practiti oners

Khasanah, N. (2020). Upaya Pemulihan UMKM di Masa Pandemi Covid-19 Melalui Pelatihan pada Pengrajin Anyaman Pandan. JCSE: Journal of Community Service and Empowerment, 1(1), 26-29. Retrieved from http://journal.stieputrabangsa.ac.id/index.php/jcse/article/view/674

Lestari, P., \& Saifuddin, M. (2020). Implementasi Strategi Promosi Produk Dalam Proses Keputusan Pembelian Melalui Digital Marketing Saat Pandemi Covid'19. Manova (Jurnal Manajemen dan Inovasi), 2(2), 23-31. https://doi.org/10.15642/manova.v3i2.301

Lionardo, A., Kurniawan, R., \& Nasirin, C. (2020). Local Government Income Revenue: A Brief Study of the Policy Impact of Pandemic Covid-19 on Tourism Recovery. Proceedings of the 5th NA International Conference on Industrial Engineering and Operations Management Detroit, Michigan, USA, August 10 - 14, 2020, 21642168.

Mistriani, N., Maria, A. D., \& Damayanti, V. (2020). Pentingnya Pelaku Industri Pariwisata Dibekali Uji Kompetensi Lewat Daring untuk Meningkatkan SDM Pariwisata di Indonesia. EDUTOURISM Journal of Tourism Research, 2(01), 32-42. http://dx.doi.org/10.46964/jtr..v2i1.325

Morrisan, M. (2015). Periklanan Komunikasi Pemasaran Terpadu. Jakarta: Kencana.

Post, T. J. (2020). Yogyakarta welcomes 1.7 million tourists in five months amid pandemic, https://www.thejakartapost.com/travel/2020/11/29/yogyakartawelcomes-1-7-million-tourists-in-five-months-amid-pandemic.html.

Sánchez-Teba, E. M., García-Mestanza, J., \& Rodríguez-Fernández, M. (2020). The Application of the Inbound Marketing Strategy on Costa del Sol Planning \& 
Tourism Board. Lessons for Post-COVID-19 Revival. Sustainability, 12(23), 9926. https://doi.org/10.3390/su12239926

Shimp, T. (2003). Periklanan Promosi \& Aspek Tambahan Komunikasi Pemasaran Terpadu, Jilid I ( edisi 5). Jakarta: Erlangga.

Soehardi, S., Permatasari, D. A., \& Sihite, J. (2020). Pengaruh Pandemik Covid-19 Terhadap Pendapatan Tempat Wisata dan Kinerja Karyawan Pariwisata di Jakarta. Jurnal Kajian Ilmiah, 1(1), 1-14. https://doi.org/10.31599/jki.v1i1.216

Surijah, E. A., Kirana, C. T., Wahyuni, N. P. J. D., Yudi, P. C., \& Astini, N. K. B. (2017). Membedah Instagram: Analisis Isi Media Sosial Pariwisata Bali. Intuisi: Jurnal Psikologi Ilmiah, 9(1), 1-17. https://doi.org/10.15294/intuisi.v9i1.9560

Trihayuningtyas, E., Wulandari, W., Adriani, Y., \& Sarasvati, S. (2018). Media sosial sebagai sarana informasi dan promosi pariwisata bagi generasi Z di Kabupaten Garut. Tourism Scientific Journal, 4(1), 1-22. https://doi.org/10.32659/tsj.v4i1.46

Umami, Z. (2015). Social Strategy pada Media Sosial Untuk Promosi Pariwisata Daerah Istimewa Yogyakarta. Interaksi: Jurnal Ilmu Komunikasi, 4(2), 195-201. https://doi.org/10.14710/interaksi.4.2.195-201

Wachyuni, S. S., \& Kusumaningrum, D. A. (2020). The Effect of COVID-19 Pandemic: How are the Future Tourist Behavior? Journal of Education, Society and Behavioural Science, 33 (4) 67-76. https://doi.org/10.9734/jesbs/2020/v33i430219

Yananda, M. R., \& Salamah, U. (2014). Branding Tempat: Membangun Kota, Kabupaten, dan Provinsi Berbasis Identitas. Jakarta: Makna Informasi. 